\title{
ATF3 Increases the Intrinsic Growth State of DRG Neurons to Enhance Peripheral Nerve Regeneration
}

\author{
Rhona Seijffers, Charles D. Mills, and Clifford J. Woolf \\ Neural Plasticity Research Group, Department of Anesthesia and Critical Care, Massachusetts General Hospital and Harvard Medical School, Charlestown, \\ Massachusetts 02129
}

\begin{abstract}
Peripheral axons of dorsal root ganglion (DRG) neurons, but not their central axons in the dorsal columns, regenerate after injury. However, if the neurons are conditioned by a peripheral nerve injury into an actively growing state, the rate of peripheral axonal growth is accelerated and the injured central axons begin to regenerate. The growth-promoting effects of conditioning injuries have two components, increased axonal growth and a reduced response to inhibitory myelin cues. We have examined which transcription factors activated by peripheral axonal injury may mediate the conditioning effect by regulating expression of effectors that increase the intrinsic growth state of the neurons. Activating transcription factor 3 (ATF3) is a prime candidate because it is induced in all injured DRG neurons after peripheral, but not central, axonal damage. To investigate if ATF3 promotes regeneration, we generated transgenic mice that constitutively express this transcription factor in non-injured adult DRG neurons. The rate of peripheral nerve regeneration was enhanced in the transgenic mice to an extent comparable to that produced by a preconditioning nerve injury. The expression of some growth-associated genes, such as SPRR1A, but not others like GAP-43, was increased in the non-injured neurons. ATF3 increased DRG neurite elongation when cultured on permissive substrates but did not overcome the inhibitory effects of myelin or promote central axonal regeneration in the spinal cord in vivo. We conclude that ATF3 contributes to nerve regeneration by increasing the intrinsic growth state of injured neurons.
\end{abstract}

Key words: ATF3; DRG; axon; nerve regeneration; myelin inhibition; growth-associated genes

\section{Introduction}

Peripheral nerve regeneration involves cytoskeletal protein assembly, formation of new membrane and expression of multiple adhesion molecules and receptors at growth cones (Goodman, 1996; Heidemann, 1996; Gordon-Weeks, 2004). This is initiated by retrograde signals from the injury site (Snider et al., 2002) that, by altering transcription of multiple genes in the neuronal cell body (Costigan et al., 2002; Xiao et al., 2002), increase the intrinsic growth state of the neurons (Plunet et al., 2002; Makwana and Raivich, 2005). That transcription is required for axonal growth is shown by the prevention of neurite elongation by RNA polymerase II inhibitors (Smith and Skene, 1997; Cai et al., 2002). Several putative growth-associated genes, including GAP-43, CAP-23, SPRR1A, and Hsp27, are induced in conditions when neurons actively grow, and can, when overexpressed in neurons, increase axonal growth (Aigner et al., 1995; Strittmatter et al., 1995; Caroni et al., 1997; Bomze et al., 2001; Bonilla et al., 2002; Williams et al., 2006). The increased intrinsic growth of DRG neurons triggered by peripheral axonal injury, "conditions" the

Received Dec. 8, 2006; revised June 5, 2007; accepted June 8, 2007.

This work was supported by the Muscular Dystrophy Association, National Institutes of Health (NS039518), and National Institute of Neurological Disorders and Stroke (NS45459 to C.D.M.). We are grateful to Dr. Pico Caroni for providing the thy 1.2 expression cassette and to Dr. Constance Cepko for providing the hPLAP gene. We thank Dr. Lin Wu, Bagayev A. Igor, and Jaquelyne L. Bitler for technical assistance.

Correspondence should be addressed to Clifford J. Woolf at the above address. E-mail: woolf.clifford@mgh.harvard.edu.

DOI:10.1523/JNEUROSCI.5313-06.2007

Copyright $\odot 2007$ Society for Neuroscience $\quad$ 0270-6474/07/277911-10\$15.00/0 neurons to grow more extensively in culture (Hu-Tsai et al., 1994; Smith and Skene, 1997) and accelerates peripheral nerve regeneration in vivo (McQuarrie et al., 1977; Bisby and Pollock, 1983; Sjoberg and Kanje, 1990). Peripheral nerve conditioning injuries also permit DRG neuronal growth on normally nonpermissive central myelin substrates (Neumann et al., 2002; Qiu et al., 2002), and in vivo, enable the central axons of DRG neurons to grow into and beyond lesions of the dorsal columns of the spinal cord (Neumann and Woolf, 1999; Neumann et al., 2005). This indicates that peripheral axonal injuries can produce a diminished response to inhibitory myelin cues in addition to increasing the growth state of the neurons. Both of these changes are likely necessary for regeneration in the CNS. However, it is unclear whether a single transcriptional regulator or parallel independent regulatory pathways control the relevant effector genes.

Several transcription factors including c-Jun, STAT3, JunD, Sox11, CREB, and ATF3 are elevated and in some cases also activated in the DRG after peripheral injury, whereas others such as ATF2 are downregulated (Jenkins and Hunt, 1991; Leah et al., 1991; Herdegen et al., 1992; Martin-Villalba et al., 1998; Schwaiger et al., 2000; Tsujino et al., 2000; Tanabe et al., 2003; Lee et al., 2004; Jankowski et al., 2006). The failure of a central axonal injury to condition DRG neurons into an actively growing state and induce growth-associated genes (Chong et al., 1994; Smith and Skene, 1997; Mason et al., 2002; Wallquist et al., 2004) suggests that transcription factors induced only after a peripheral axonal injury are the trigger that conditions neurons to regener- 
ate. ATF3 is highly induced in all injured DRG neurons after peripheral but not central axonal injury and is downregulated on reinnerevation of the peripheral target (Tsujino et al., 2000; Bloechlinger et al., 2004). Delivery of ATF3 to cultured adult DRG neurons, neonatal SCG neurons and PC12 cells enhances neurite outgrowth (Nakagomi et al., 2003; Pearson et al., 2003; Seijffers et al., 2006).

We now have generated transgenic mice that constitutively express ATF3 in non-injured adult DRG neurons to evaluate the specific role of this transcription factor on intrinsic growth.

\section{Materials and Methods}

Generation of ATF3 transgenic mice. ATF3 mouse coding sequence (cds) upstream to an IRES element and the human placental alkaline phosphatase (hPLAP) gene were cloned as a $2.8 \mathrm{~kb}$ fragment into the XhoI site of the Thy-1.2 expression cassette (Caroni, 1997). The transgene encompassing the Thy-1.2-regulating elements, ATF3 cds, IRES element, and the hPLAP reporter gene was microinjected into fertilized B6C3F1 mouse oocytes, for the generation of transgenic mice. Three sets of primers verified that the whole transgene had integrated into the mouse genome. Primer 1, 5'-GAG ATG TCA GTC ACC AAG TCT G-3', and primer 2, 5' -GGA TAA AGA GGT TCC TCT CGT C-3', amplify a fragment in the ATF3 cds. Another set is comprised of one primer situated on the ATF3 cds and the other on the Thy-1.2 promoter: primer 3, 5'-AGG ACC TTA GGC AGT GTC ACT C-3', and primer $4,5^{\prime}$-CTT CCT TGA CAA AGG GTG TCA G- $3^{\prime}$. A third is specific for the hPLAP gene: primer 5, 5'-GAC AAA CAT GTG CCA GAC AGT G-3', and primer 6, 5' -AAC ATG TAC TTT CGG CCT CCA C-3' (see Fig. 1). Mice with the transgene in their genome were bred on to a $\mathrm{C} 57 \mathrm{Bl} / 6$ background.

Surgery. Procedures were performed in accordance with the Massachusetts General Hospital Animal research regulations. Experiments were performed under isoflurane anesthesia (Baxter, Deerfield, IL) in adult mice 8 weeks and older. Sciatic nerve transection (SNT) was performed at mid-thigh level; the exposed nerve was ligated, and the nerve was transected distally to the ligation. For crush injuries the sciatic nerve was crushed with smooth forceps for $15 \mathrm{~s}$ at the proximal thigh level, and the injury site was marked with a 10-0 epineural suture. Dorsal column lesion (DC) was performed by a hemi-laminectomy at T10, transecting the dorsal column on both sides with ophthalmic microscissors.

Primary adult DRG neuron culture. DRGs were digested in collagenase $(5 \mathrm{mg} / \mathrm{ml}) /$ dispase $(1 \mathrm{mg} / \mathrm{ml})$ (Roche, Indianapolis, IN), dissociated in $0.25 \%$ trypsin (Cellgro, Herndon, VA) and mechanically triturated through a polished Pasteur pipette to a single-cell suspension. Cells were purified on $10 \%$ BSA in PBS solution (Sigma, St. Louis, MO) to enrich the cultures for neurons $(>90 \%)$. Then the cells were plated in a tissue culture eight-well chamber slide dish (Nalge Nunc, Naperville, IL) coated with poly-D-lysine and laminin (Sigma) or poly-D-lysine and $0.75 \mathrm{mg}$ of myelin per well and cultured in Neurobasal medium (Invitrogen, Carlsbad, CA) supplemented with B27 supplement, penicillin, streptomycin, 1 mM L-glutamine, $50 \mathrm{ng} / \mathrm{ml} \mathrm{NGF}, 2 \mathrm{ng} / \mathrm{ml}$ GDNF, and $10 \mathrm{~mm}$ AraC at $37^{\circ} \mathrm{C}$.

Alkaline phosphatase activity assay. Whole-mount alkaline phosphatase (hPLAP) activity was assayed in freshly dissected mouse DRGs, fixed in $0.5 \%$ glutaraldehyde, washed in PBS, incubated in prewarmed PBS at $65^{\circ} \mathrm{C}$ for $30 \mathrm{~min}$, washed in $100 \mathrm{~mm}$ Tris- $\mathrm{HCl}, \mathrm{pH}$ 9.5, $100 \mathrm{~mm} \mathrm{NaCl}, 50$ $\mathrm{mm} \mathrm{MgCl}_{2}, 0.1 \%$ Tween 20 , and $0.48 \mathrm{~g} / \mathrm{L}$ levamisole, and incubated overnight with BM purple AP substrate (Roche) in the dark.

Immunostaining. Dissociated DRG neurons or $7-\mu \mathrm{m}$-thick DRG cryosections were fixed in $4 \%$ paraformaldehyde, washed in PBS, blocked in $2 \%$ goat serum $/ 0.3 \%$ Triton X-100 in PBS, and processed with 1:500 anti-ATF3 (rabbit polyclonal) antibody (Santa Cruz Biotechnology, Santa Cruz, CA), 1:50 anti-c-Jun (rabbit monoclonal) antibody (Cell Signaling Technology), 1:800 anti- $\beta$-tubulin III (mouse monoclonal) antibody (Sigma), 1:1000 anti-GAP-43 (rabbit polyclonal) (Chemicon, Temecula, CA), 1:1000 anti-SPRR1A (rabbit polyclonal) (Abcam, Cambridge, MA), followed by 1:200 Cy3-anti-rabbit (goat polyclonal) antibody (Jackson ImmunoResearch, West Grove, PA).
Western blot analysis. Protein was extracted from adult L5 and L6 DRG by using RIPA buffer and concentration determined by using the BCA kit (Pierce, Rockford, IL). Then $20 \mu \mathrm{g}$ of protein was resolved on a $4-15 \%$ SDS-PAGE gradient gel (Bio-Rad, Hercules, CA). The gel was transferred to $0.45 \mu \mathrm{m}$ PVDF membrane (Millipore, Bedford, MA), blocked in 5\% skim milk, $0.05 \%$ Tween 20 in PBS, and incubated with 1:500 anti-ATF3 (rabbit polyclonal) antibody (Santa Cruz Biotechnology). The membrane was stripped and reblotted with 1:1000 anti-c-Jun (rabbit monoclonal), 1:400 anti- $\beta$-tubulin III (mouse monoclonal) (Sigma), 1:1000 anti-GAP-43 (rabbit polyclonal) (Chemicon), followed by 1:5000 horseradish peroxidase-conjugated goat anti-rabbit secondary antibody (Amersham, Arlington Heights, IL) and visualized by using enhanced chemiluminescence detection (PerkinElmer Life Sciences, Boston, MA).

Neurite outgrowth assay. Neurite outgrowth was assayed in DRG neurons cultured on laminin or myelin for either 17 or $45 \mathrm{~h}$. The cells were fixed with $4 \%$ paraformaldehyde and immunostained with anti- $\beta$ tubulin III. Neurons with any process were defined as bearing neurites. The percentage of neurons bearing neurites was calculated and neurite length measured with the NIH ImageJ software. The longest process for 100 individual neurons in each replicate was measured and averaged. A neurite length frequency histogram was used to display the neurite length distribution.

Measurement of nerve regeneration. The nerve pinch test was used to determine the rate of in vivo peripheral nerve regeneration (Sjoberg and Kanje, 1990; Mills et al., 2005). This technique is used to evaluate enhanced regeneration, and is performed between 2 and $4 \mathrm{~d}$ after injury. At $2 \mathrm{~d}$ after sciatic crush, anesthesia was induced with $2.5 \%$ isoflurane, and the left sciatic nerve was exposed. Animals were brought to a light plane of anesthesia ( $1 \%$ isoflurane). Starting distally, a series of pinches using fine smooth forceps were delivered to the sciatic nerve, moving proximally toward the injury site. We determined the rate of regeneration by measuring the distance from the injury site, which was marked with an epineural suture under a dissecting microscope, to the most distal point on the nerve that produced a reflex withdrawal response when pinched. GAP-43 immunostaining was used to characterize regeneration histologically, because GAP-43 expression is highly induced in regenerating fibers in the injured sciatic nerve $2 \mathrm{~d}$ after injury. Sciatic nerves were sectioned serially at $10 \mu \mathrm{m}$ thick, and the mean number of GAP-43immunoreactive fibers per section was determined in three sections ( 30 $\mu \mathrm{m}$ apart) per animal, $1.5 \mathrm{~mm}$ beyond the injury site. The mean number of fibers per section per animal was determined for three animals in each treatment group.

Central regeneration was assayed 4 weeks after DC injury by injection of $2 \mathrm{ml}$ of $1 \%$ B-HRP (List Biologic, Campbell, CA) into the sciatic nerve.

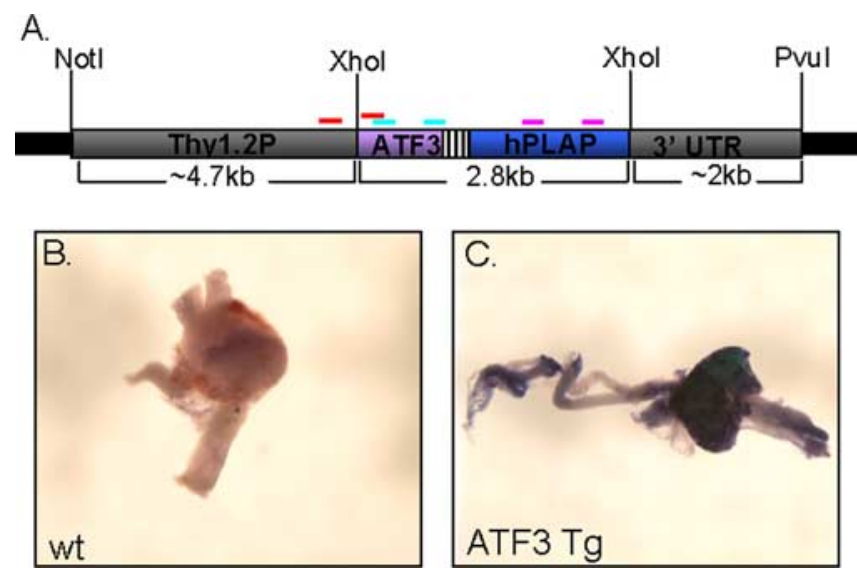

Figure 1. Generation of ATF3 transgenic mice. A, ATF3 and a hPLAP reporter were cloned bicistronicly into the $X$ hol site of the thy 1.2 expression cassette. The transgenes and regulatory elements were excised with Notl/Pvul and used to generate ATF3 transgenic mice. Primer sets 1 and 2 (blue bands), 3 and 4 (red bands), and 5 and 6 (pink bands) were used for genotyping. $\boldsymbol{B}, \boldsymbol{C}$, The wt $(\boldsymbol{B})$ and ATF3 (C) transgenic DRG whole mounts that were stained for alkaline phosphatase activity show expression of the reporter in the transgenic mouse DRG. 

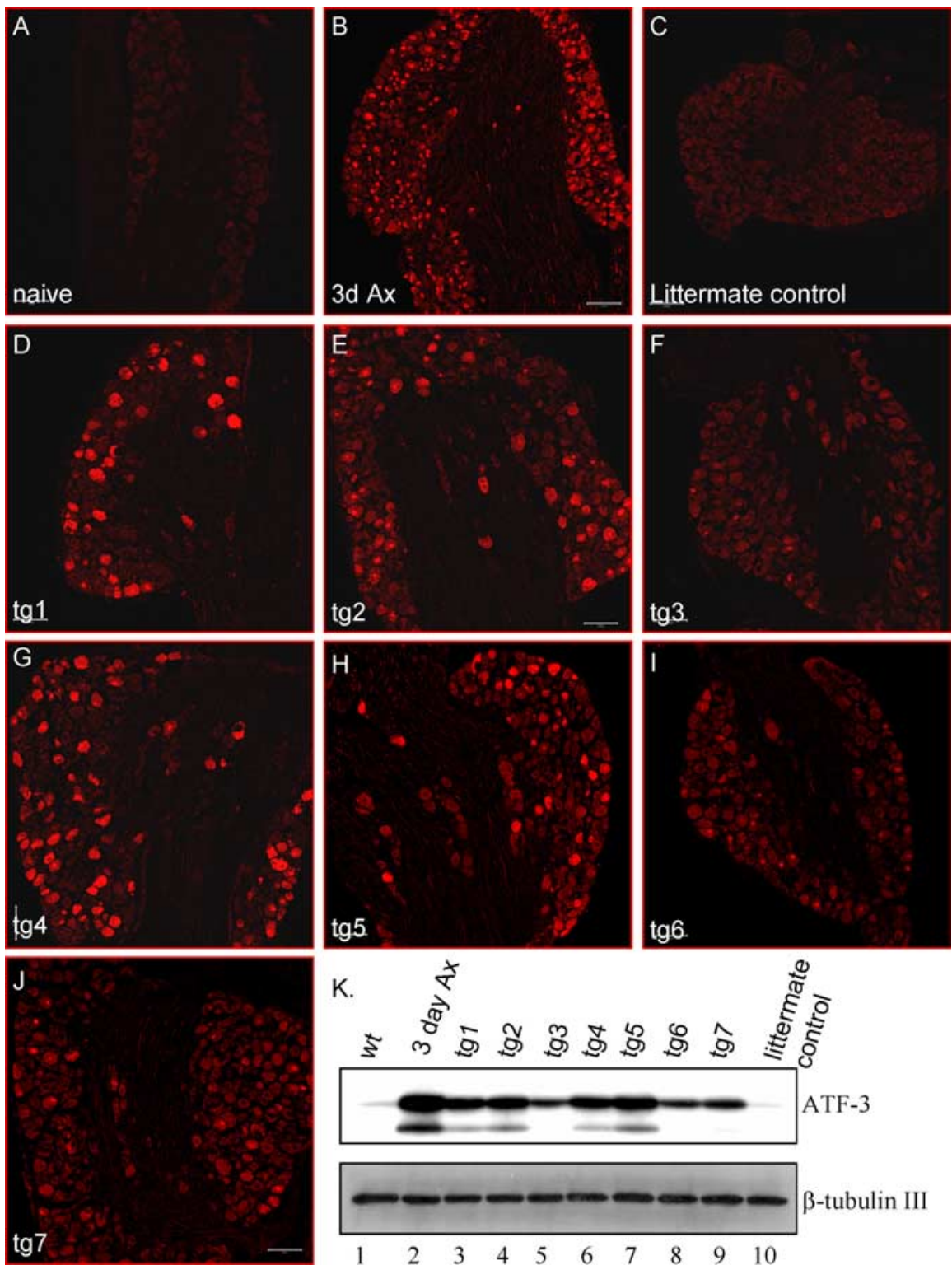

Figure 2. Constitutive ATF3 expression in L5 DRGs of non-injured ATF3 transgenic mice. $A-J$, Immunostaining for ATF3 in L5 DRGs of wt $(\boldsymbol{A})$, wt 3 d post-SNT $(\boldsymbol{B})$, a littermate control $(\boldsymbol{C})$, and seven different non-injured ATF3 transgenic mouse lines, $\operatorname{tg} 1-\operatorname{tg} 7$ $(\boldsymbol{D}-\boldsymbol{J})$. Scale bars, $100 \mu \mathrm{m} . \boldsymbol{K}$, Western blot analysis for ATF3 in L5 and L6 DRGs. Lane 1, wt; lane 2, 3 d post-SNT; lanes 3-9, non-injured tg1-tg7; lane 10, littermate control.

At $4 \mathrm{~d}$ later horizontal sections ( $10 \mathrm{~mm}$ thick) through the upper lumbar and thoracic spinal cord were processed for peroxidase activity (Neumann and Woolf, 1999). Labeled fibers were traced by using a camera lucida and the length of fibers regenerating from the center of the lesion site and rostral measured. All measurements were blinded to the mouse genotype/treatment.

Real-time quantitative PCR. The L5 and L6 DRGs of four to five mice for each group were pooled, RNA was extracted via Trizol (Invitrogen) and purified with the RNeasy kit (Qiagen Sciences, Germantown, MD), and genomic DNA eliminated with DNaseI digestion (Qiagen, Hilden, Germany). cDNA was generated, using the first strand synthesis kit (Invitrogen). Mouse-specific primers for ATF3, c-Jun, GAP-43, CAP-23, SPRR1A, $\alpha 7$ integrin, Hsp27, STAT3, and GAPDH (SuperArray, Fredrick, MD) were amplified by polymerase chain reaction in the presence of SYBR green (SuperArray). The levels of the target gene were compared with GAPDH, and fold difference was calculated compared with a littermate control.

\section{Results}

Creation of ATF3 transgenic mice

Mouse ATF3 cDNA and the hPLAP reporter were cloned as a bicistronic expression cassette into the thy 1.2 expression vector. The thy 1.2 regulatory elements enable postnatal neuronal-specific expression with a sustained expression through adulthood that is not affected by nerve injury (Caroni, 1997). The transgenes and the thy1.2 regulatory elements bordered by NotI and $P v u I$ were used for microinjection (Fig. 1). The resulting progeny were genotyped, using primer sets spanning ATF3, hPLAP, and the thy1.2 promoter (Fig. 1A). Seven ATF3 mouse lines were produced and tested for ATF3 transgene protein expression in DRG neurons. As a first screen a whole-mount alkaline phosphatase assay was performed on DRGs from the ATF3 mouse lines to identify hPLAP reporter activity. The hPLAP reporter expression was identified clearly in the DRG from ATF3 transgenic mice, with no expression in control wt mice (Fig. $1 B, C)$. Next the amount of ATF3 protein its distribution in the DRG of non-injured ATF3 transgenic mice lines was determined by immunostaining and Western blot analysis (Fig. 2). ATF3 protein levels were compared with control wt noninjured and injured DRG neurons (3 d after a sciatic nerve transection) and with littermate non-injured controls. Almost no ATF3 expression was detected in noninjured wt DRG and littermate controls, and high expression was detected in wt DRG $3 \mathrm{~d}$ after peripheral axotomy (Fig. $2 A-C, K$, lanes $1,2,10)$. The amount of ATF3 protein expressed differed between the different ATF3 transgenic lines tg1-tg7 (Fig. 2D-J,K, lanes 3-9). ATF3 in the transgenic mouse lines was detected in both the nucleus and cytoplasm of DRG neurons, with no expression in nonneuronal cells. All ATF3 transgenic mouse lines were viable and fertile and showed no obvious behavioral abnormalities. Two of the ATF3 mouse lines that expressed levels of ATF3 most comparable to the ATF3 levels induced in peripheral nerve-injured wt DRG neurons were used for additional analysis.

\section{Peripheral nerve regeneration is enhanced in ATF3 transgenic mice}

The rate of peripheral nerve regeneration $2 \mathrm{~d}$ after a sciatic nerve crush was measured via the nerve pinch test. An early time point of $2 \mathrm{~d}$ after injury was used to evaluate whether ATF3 constitutively expressed before the injury can prime the neurons for growth. The pinch test determines the extent of axonal regrowth after a crush injury by measuring the distance between the point of injury and the most distal point on the nerve that produces a reflex withdrawal response when pinched with forceps (Sjoberg and Kanje, 1990; Mills et al., 2005). The test only measures 

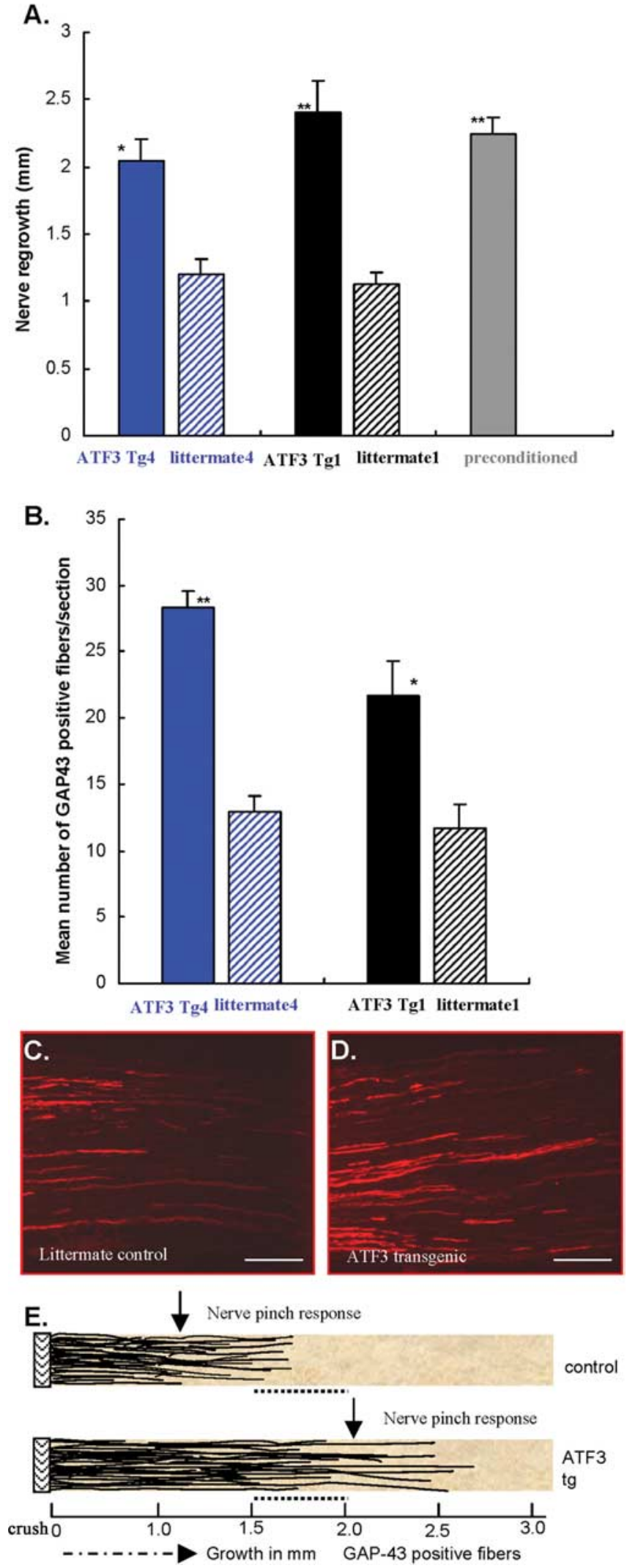

Figure 3. ATF3 enhances peripheral nerve regeneration. $\boldsymbol{A}$, Sciatic nerve regrowth assayed by the nerve pinch test $48 \mathrm{~h}$ after crush of the sciatic nerve increases in two separate ATF3 transgenic lines (tg1 and tg4; black and blue bars) compared with their littermate controls (striped bars). Preconditioned wt (sciatic conditioning crush $3 \mathrm{~d}$ before the second test crush) were used as positive controls for enhanced growth (gray bars); $n=6-9$ per group. ${ }^{*} p<0.01$; ${ }^{* *} p<0.001$; Student's $t$ test. B, GAP-43 expression in regenerating fibers $48 \mathrm{~h}$ after nerve crush in two ATF3 transgenic mice lines, $\operatorname{tg} 1$ and $\operatorname{tg} 4$, compared with littermate controls. ${ }^{*} p<$ growth of sensory axons because pinch of motor axons does not elicit withdrawal reflexes.

The rate of regeneration was enhanced in two separate ATF3 transgenic mouse lines compared with littermate controls (Fig. $3 A$ ). Enhanced regeneration was also found in control wt mice preconditioned by a crush injury $3 \mathrm{~d}$ before a second crush injury. The increased early regeneration rate in the two ATF3 transgenic mice lines was similar to that produced by the preconditioning lesion (Fig. 3A). The extent of sciatic nerve regeneration was additionally analyzed, using GAP-43 as a marker for regenerating axons. The number of GAP-43-positive fibers $1.5 \mathrm{~mm}$ distal to the crush site, measured $2 \mathrm{~d}$ after the injury, doubled in the ATF3 transgenic mice compared with littermate controls (Fig. $3 B-D$ ). The acceleration in nerve regeneration in the ATF3 transgenic mice as revealed both by the pinch test and GAP- 43 reactivity is illustrated in Figure 3E. GAP-43 expression is not enhanced in the transgenic mice (see below) enabling its use as an axonal marker. Although denervated Schwann cells do express GAP-43 (Curtis et al., 1992), the level is much lower than that in regenerating axons, and under the staining conditions used in these experiments, was not detected. Enhanced peripheral nerve regeneration was found in two independent ATF3 transgenic mouse lines indicating that the growth effect was not a result of the site of DNA integration, but of the ATF3 expression. ATF3 therefore increases peripheral axonal growth in vivo to an extent equivalent to the increase produced by a conditioning lesion implying that uninjured DRG neurons in the ATF3 transgenic mice are primed for growth before axonal injury.

\section{Failure of regeneration after dorsal column injury}

To test if ATF3 enhances regeneration in the CNS, we performed a dorsal column injury, injuring the axons of medium and large DRG neurons that ascend up the dorsal columns in the spinal cord to the gracile nucleus. B-HRP was injected into the sciatic nerve to trace dorsal column axons emanating from the nerve 4 weeks after the spinal cord injury. In wt mice no regeneration occurred in the dorsal column and similarly no regeneration developed in ATF3 transgenic mice (Fig. $4 A, B, D$ ). In wt mice in which a conditioning sciatic nerve transection was performed $4 \mathrm{~d}$ before the dorsal column injury, growth occurred into the lesion site in the spinal cord with sprouting caudal to the injury, many axons extending into the lesions site and a few axons extending rostrally (Fig. $4 C, D$ ). None of these three manifestations of enhanced growth were observed in the non-preinjured wt or ATF3 transgenic mice. Although constitutive ATF3 expression promotes peripheral regeneration it does not fully mimic the conditioning effect that enables some regeneration in the CNS.

ATF3 enhances neurite outgrowth of adult DRG neurons on a permissive substrate but fails to overcome myelin inhibition To determine if some aspects of the spinal cord environment may inhibit axonal growth in the ATF3 transgenic mice after a dorsal column injury as it does in intact wt but not preconditioned wt

0.01 ; ${ }^{* *} p<0.001$; Student's $t$ test. $C, \boldsymbol{D}$, Representative nerve sections stained for GAP-43 in the littermate control and ATF3 transgenic line, respectively. Scale bars, $200 \mu \mathrm{m}$. $\boldsymbol{E}$, Graphic representation of the extent of regrowth detected by nerve pinch test and GAP-43immunoreactive axons in ATF3 transgenic (bottom panel) and littermate control (top panel). 0 $\mathrm{mm}$, Crush point; black thin lines, GAP-43-positive regenerating fibers; dashed arrow, direction of fiber growth from the point of crush toward the peripheral target; filled arrow, average distance point a flinch response appears when the nerve is pinched $2 \mathrm{~d}$ after injury. The dotted line between 1.5 and $2 \mathrm{~mm}$ represents the area of GAP- 43 fiber quantification. 

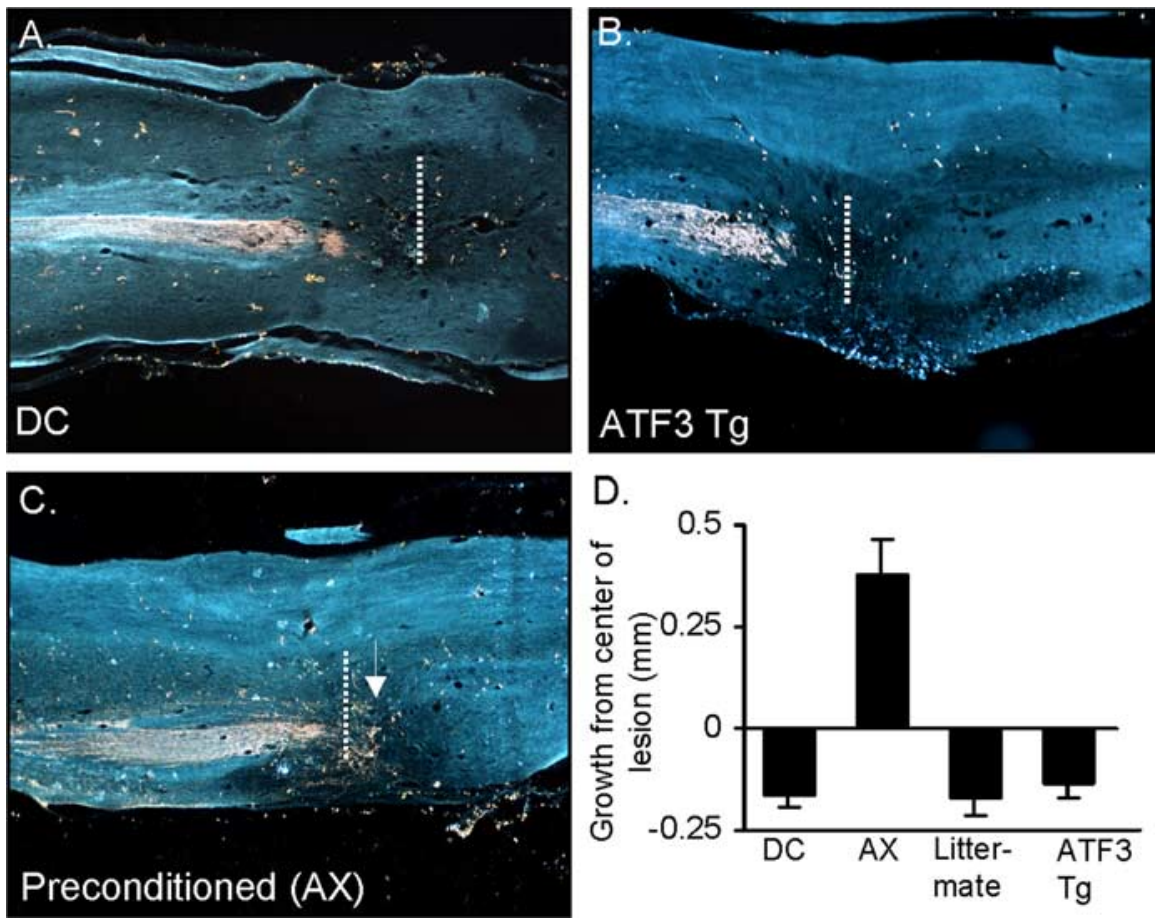

Figure 4. Constitutive ATF3 expression does not promote regeneration after dorsal column injury. $\boldsymbol{A}-\boldsymbol{C}$, Representative spinal cord sections stained for B-HRP show the extent of growth 4 weeks after dorsal column injury in wt mice $(\boldsymbol{A})$, ATF3 transgenic mice $(\boldsymbol{B})$, and preconditioned (with a sciatic nerve transection) wt mice (C).D, Preconditioning, but not constitutive, ATF3 expression increased growth into the lesion site.

mice, we cultured adult DRG neurons on a permissive laminin or on an inhibitory central myelin substrate. Adult DRG cultures were prepared from two ATF3 transgenic mouse lines and their control littermates. The neurons were plated and $17 \mathrm{~h}$ later, stained for $\beta$-tubulin III. When grown on the laminin substrate the increase in the proportion of neurons bearing neurites in ATF3 transgenic mice lines compared with littermate controls was small (5-7\%) (Fig. 5A). However, neurite length increased substantially (Fig. $5 B-D$ ). The enhancement in neurite outgrowth was comparable to that found by delivering ATF3 with HSV based amplicon vectors to cultured adult DRG neurons (Seijffers et al., 2006). In contrast, no significant difference between ATF3 transgenics and littermate control DRG neurons was identified when cultured on myelin for $17 \mathrm{~h}$. The percentage of DRG neurons bearing neurites $(6.7 \pm 0.9$ tg vs $6.6 \pm 0.5 \%$ control littermate) and average neurite length $(94.5 \pm 4.3 \mu \mathrm{m}$ tg vs $90.5 \pm 7.4 \mu \mathrm{m}$ control littermates) were not different, nor was the neurite length frequency distribution (Fig. $5 E$ ). In addition, no significant difference between ATF3 transgenic mice and littermate controls was observed after culturing the DRG neurons for $45 \mathrm{~h}$ on myelin in either the percentage of neurons bearing neurites (39.8 \pm 2.7 and $34.8 \pm 1.8 \%$, respectively) or average neurite length $(211 \pm 16.7 \mu \mathrm{m}$ for tg compared with $167.02 \pm 8.9 \mu \mathrm{m}$ in the littermates). The neurite length frequency distribution also did not differ significantly, although at $45 \mathrm{~h}$ the growth was greater than at $17 \mathrm{~h}(\mathrm{~F})$. Constitutive ATF3 expression increases neuronal growth on a permissive environment but, unlike peripheral nerve-conditioning lesions (Neumann et al., 2002; Qiu et al., 2002), does not overcome the inhibition produced by CNS myelin in culture. This may at least in part explain the failure of central regeneration after dorsal column injury in the transgenic mice.
Change in growth-associated gene expression in ATF3 transgenic mice Quantitative real-time PCR was performed to test for ATF3-dependent changes in the transcription of putative growth associated genes. Transcript levels for ATF3, Hsp27, SPRR1A, c-Jun, CAP23, GAP-43, $\alpha 7$ integrin and STAT3 were measured and normalized to GAPDH (Fig. 6) in L5 and L6 DRGs of non-injured ATF3 transgenic, littermate control and wt mice $3 \mathrm{~d}$ after a sciatic nerve transection. ATF3 mRNA levels in the ATF3 transgenic mice were similar to that found after axotomy in wt mice (Fig. 6A). Hsp27 is the only ATF3 regulated gene so far described in neurons (Nakagomi et al., 2003) and its levels increased in the ATF3 transgenic mice (Fig. 6B). SPRR1A (8.48-fold) and c-Jun (1.93-fold) levels also elevated in the DRGs of non-injured ATF3 transgenic mice, but CAP-23, GAP-43, $\alpha 7$ integrin, and STAT3 levels did not change despite their all being induced by peripheral nerve injury (Fig. 6C-H). Immunostaining and Western blot analysis confirmed that c-Jun and SPRR1A protein were increased in intact ATF3 transgenic mice DRGs, with no change in GAP-43 (Fig. 7). ATF3 expression in non-injured DRG neurons therefore is adequate to trigger an upregulation of some, but not all, peripheral injury-induced putative growth-associated genes.

\section{Discussion}

Peripheral nerve injury, unlike axonal damage within the central nervous system, triggers injured neurons into an actively growing state, an essential prerequisite for successful regeneration. Once primary sensory neurons are primed by peripheral axonal injury, they grow more rapidly in response to a subsequent lesion, in what has become known as the conditioning effect (Richardson and Issa, 1984; Sjoberg and Kanje, 1990; Oudega et al., 1994). In addition to increasing growth on permissive environments such as laminin or Schwann cells, the peripheral conditioning lesion also overcomes the effects of myelin growth inhibitory cues. Injury to the peripheral axon of a primary sensory neuron enables, for example, its central axon in the dorsal columns to regenerate into and beyond a lesion site (Neumann and Woolf, 1999; Neumann et al., 2005). The inhibition of growth evoked by myelin of oligodendrocyte origin is attributable to several membraneassociated proteins that include Nogo, myelin-associated glycoprotein, and OMgp (Mukhopadhyay et al., 1994; Chen et al., 2000; GrandPre et al., 2000; Domeniconi et al., 2002; Liu et al., 2002; Wang et al., 2002). Other inhibitory cues include extracellular matrix molecules such as chondroitin sulfates (Silver and Miller, 2004). The reduction in the response of neurons to these inhibitory cues after peripheral nerve injury could be attributable to a modification or downregulation in the receptors that comprise the Nogo receptor complex. Expression of p75 in DRG neurons is downregulated after peripheral injury (Krekoski et al., 1996; Zhou et al., 1996) and it is possible that levels of NgR1, Troy or lingo are also decreased (GrandPre et al., 2002; Mi et al., 2005; Park et al., 2005; Shao et al., 2005). Changes in the expression or 
modification of downstream signal transduction paths or other effectors that lead to growth cone collapse may also contribute (Lehmann et al., 1999; Dergham et al., 2002; Sivasankaran et al., 2004; Spencer and Filbin, 2004; Domeniconi et al., 2005; Koprivica et al., 2005). The conditioning effect contributes therefore, both to an enhancement of axonal growth and a diminished response to myelin inhibitory signals.

Peripheral injury is accompanied by altered transcription of $>1000$ genes in the DRG (Costigan et al., 2002; Xiao et al., 2002). These include induction or increased expression of several candidate growth-associated genes with established or postulated roles in the formation or elongation of neurites and that may constitute the intrinsic, transcriptionally regulated molecular machinery necessary for axonal growth (Snider et al., 2002; Makwana and Raivich, 2005). We hypothesized that ATF3 contributes to nerve regeneration by coordinating expression of growth-associated genes, both because it is the only known transcription factor induced in all injured DRG neurons after a peripheral but not central axonal injury (Tsujino et al., 2000; Bloechlinger et al., 2004), and because it enhances neurite outgrowth in culture (Nakagomi et al., 2003; Pearson et al., 2003; Seijffers et al., 2006). We now show that ATF3 does indeed enhance the rate of regeneration in the PNS to an extent similar to wt mice preconditioned by a nerve injury. We conclude that ATF3 may be a major driver of the peripheral nerve regeneration-promoting effects of conditioning lesions. However, constitutive ATF3 expression in non-injured adult DRG neurons does not, unlike a peripheral nerve injury, overcome the inhibitory effects of central myelin in vivo or in vitro. This indicates that constitutive ATF3 expression is not sufficient on its own to fully mimic the conditioning effects to trigger central axonal regeneration. These observations do not however exclude the possibility that ATF3 still contributes to regeneration in the CNS. ATF3 may, for example, contribute to the reduced response to inhibitory myelin cues after peripheral nerve injury but only when acting together with other transcription factors. ATF3 can form functional heterodimers with leucine zipper transcription factors such as c-Jun and CREB and both are upregulated in DRG neurons by nerve injury. ATF3 may also interact with nonleucine zipper transcription factors upregulated after peripheral injury, such as, STAT3. This could be via
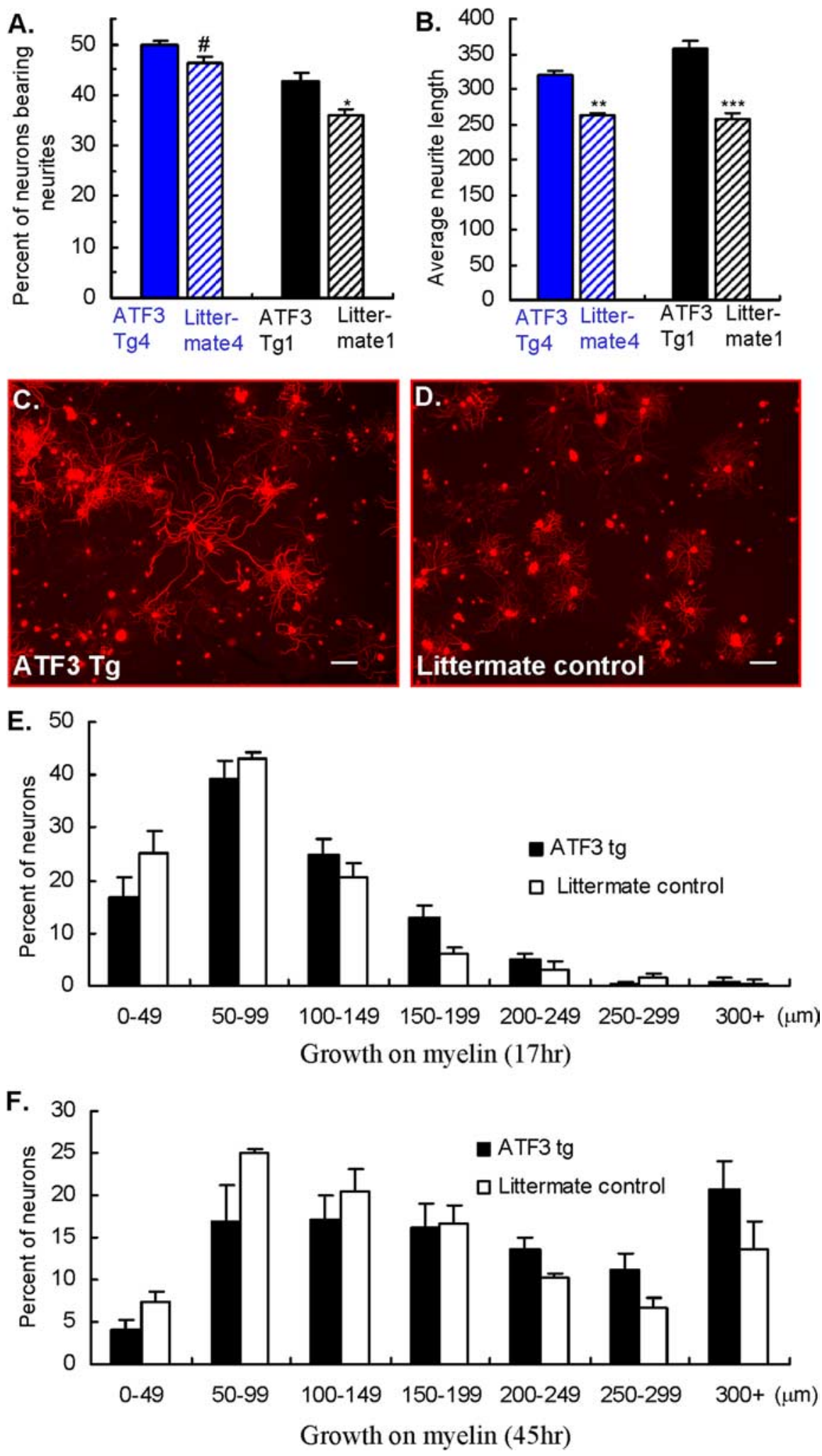

Figure 5. ATF3 enhances neurite outgrowth in a permissive environment but does not overcome myelin inhibition. $\boldsymbol{A}, \boldsymbol{B}$, The percentage of neurons extending neurites $(\boldsymbol{A})$ and the average neurite length measured after $17 \mathrm{~h}$ in culture $(\boldsymbol{B})$ increased in two independent ATF3 transgenic mouse lines, $\operatorname{tg} 1$ (black bars) and tg4 (blue bars), compared with their littermate controls (striped bars) when cultured on laminin. Mean \pm SEM; $n=6 .{ }^{*} p<0.05 ;{ }^{*} p<0.01 ;{ }^{* *} p<0.001 ;{ }^{* *} p<0.0001$; Student's $t$ test. $\boldsymbol{C}, \boldsymbol{D}$, Representative images immunostained for $\beta$-tubulin III in ATF3 transgenic and littermate control, respectively. Scale bars, $100 \mu \mathrm{m} . \boldsymbol{E}, \boldsymbol{F}$, Neurite length frequency histograms of DRG neurons cultured on myelin for $17 \mathrm{~h}(\boldsymbol{E})$ and $45 \mathrm{~h}(\boldsymbol{F})$ show no significant difference between transgenic mice and littermate controls. Mean $\pm \mathrm{SEM} ; n=6 ; p>0.05 ;$ Student's $t$ test. 
A.

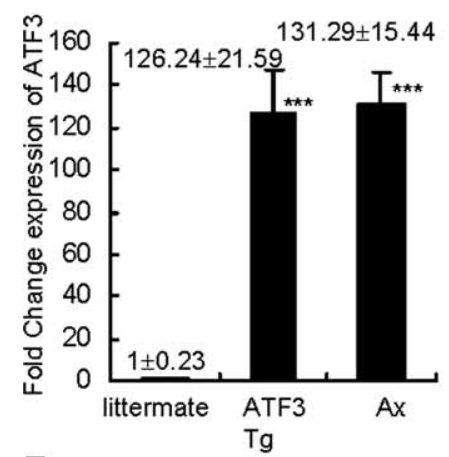

E.

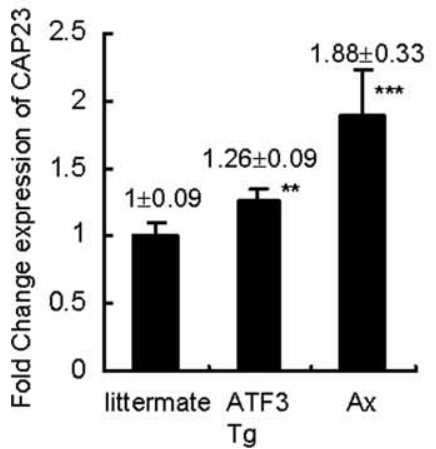

B.

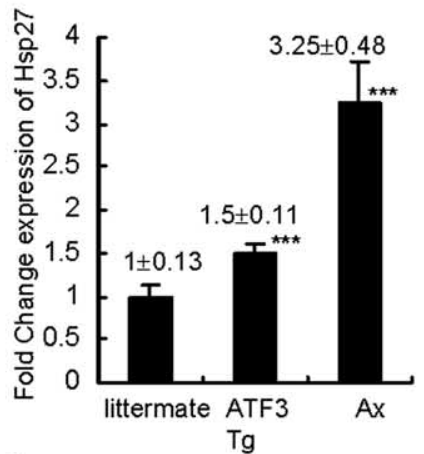

F.

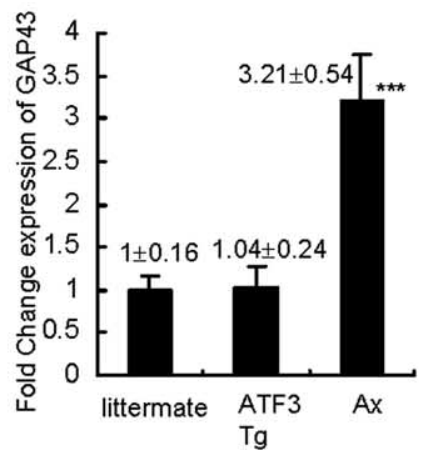

C.

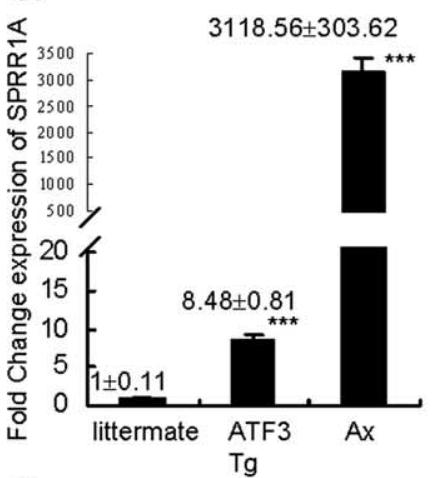

G.

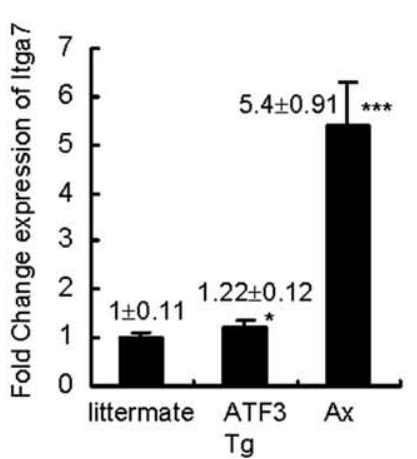

D.

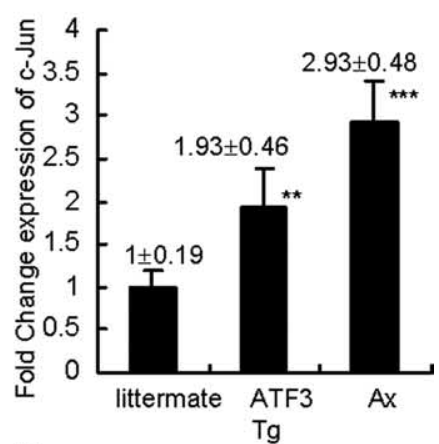

H.

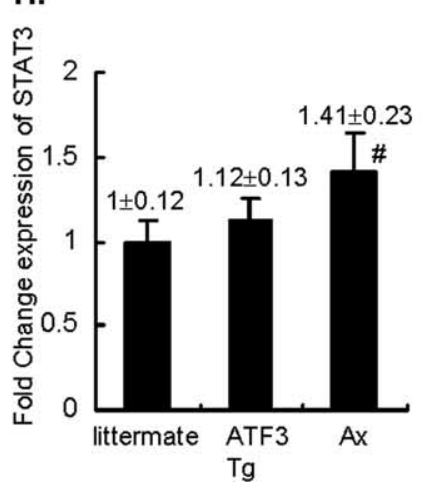

Figure 6. ATF3-dependent transcriptional changes of growth-associated genes. Fold change in the mRNA levels of ATF3, Hsp27, SPRR1A, c-Jun, CAP-23, GAP-43, $\alpha 7$ integrin, and STAT3 ( $\boldsymbol{A}-\boldsymbol{H}$ ) in L5 and L6DRGs of non-injured ATF3 transgenic mice, wt $3 \mathrm{~d}$ after sciatic nerve transection (Ax), and non-injured littermate control was measured by quantitative real-time PCR. Mean \pm SD; $n=$ 6. ${ }^{\#} p<0.05 ;{ }^{*} p<0.01 ;{ }^{* *} p<0.001 ;{ }^{* * *} p<0.0001$; Student's $t$ test.

coactivators or by synergizing with transcription factors that bind to adjacent DNA binding sites. Furthermore, peripheral nerve injury may produce post-translational modifications in ATF3 that are required for its full function, and these may not be present in non-injured neurons in the transgenic mice. Studies that force ATF3 expression in DRG neurons in concert with other transcription factors, as well as experiments that involve both preconditioning injuries and ATF3 knockdown are required to evaluate the extent to which this transcription factor contributes to all of the different aspects of the conditioning paradigm; induction of growth associated genes, increased axonal growth, and decreased response to inhibitory cues.

Constitutive ATF3 expression in non-injured adult DRG neurons did not produce all of the changes in expression of a panel of growth-associated genes that are induced by peripheral nerve injury. In the transgenic DRGs we found an increase in c-Jun, Hsp27, and SPRR1A but not of GAP-43, CAP-23, $\alpha 7$ integrin, or STAT3. Nevertheless, the ATF3-regulated expression of these and perhaps other genes in non-injured neurons are sufficient to prime the neurons for enhanced peripheral axonal regeneration. However, as mentioned above, additional transcription factors and post-translational changes induced after nerve injury may interact and/or act in concert with ATF3 to produce the complete set of ATF3 dependent transcriptional changes. Constitutive ATF3 expression in the transgenic mice although sufficient to enhance axonal growth may not fully reflect the entire role of this transcription factor in nerve regeneration after injury.

ATF3 functions both as an activator and a repressor to control expression of a variety of genes (Hai et al., 1999; Hai and Hartman, 2001). In neurons, the only identified ATF3 target so far is the heat shock protein Hsp27, a peripheral nerve injury-induced intrinsic neuronal survival factor (Benn et al., 2002). ATF3 binds directly to the Hsp27 promoter and activates its expression in PC12 cells (Nakagomi et al., 2003). ATF3 transgenic mice show enhanced Hsp27 expression, confirming in vivo that Hsp27 is an ATF3 target gene. In addition to its role as a survival factor, Hsp27 enhances neurite outgrowth in cultured adult DRG neurons (Williams et al., 2006), possibly as a result of interactions with the cytoskeleton, and may therefore contribute to the enhanced peripheral nerve regeneration in the transgenic mice. The growthassociated gene SPRR1A, which is massively induced in all injured DRG neurons, is also elevated in non-injured neurons in ATF3 transgenic mice, although to a more limited extent. SPRR1A promotes axonal outgrowth by interacting with actin structures (Bonilla et al., 2002). ATF3 may regulate expression of SPRR1A either by binding directly to the promoter or affecting other transcription factors. The SPRR1A promoter contains functional AP-1 binding sites (Sark et al., 1998; Pradervand et al., 2004). AP-1 sites are recognized by homodimers of Jun or hetreodimers of Jun/Fos and ATF/CREB bZIP transcription factors (Hai and Curran, 1991). Because the levels of SPRR1A in injured DRGs are higher than in non-injured DRG in the ATF3 transgenic mice, other downstream signals in addition to ATF3 are likely to govern SPRR1A expression. $\mathrm{C} / \mathrm{EBP} \beta$, for example, is induced after peripheral nerve injury and a functional $\mathrm{C} / \mathrm{EBP} \beta$ binding site is located on the SPRR1A promoter (Pradervand et al., 2004; Nadeau et al., 2005).

The upregulation of c-Jun in the DRG of ATF3 transgenic mice implies that ATF3 may control c-Jun expression. A neuronal specific knockout of c-Jun decreases the rate of regeneration of injured facial motor neuron axons (Raivich et al., 2004), and JNK inhibitors reduce neurite outgrowth (Lindwall et al., 2004). 
Both ATF3 and c-Jun promoters contain functional AP-1 sites (Morooka et al., 1995; Cai et al., 2000) and c-Jun and ATF3 may therefore regulate each other's expression. ATF3 synergizes with c-Jun to enhance neurite outgrowth (Pearson et al., 2003; Lindwall et al., 2004). The growthassociated gene $\alpha 7$ integrin (Werner et al., 2000) is downregulated in the facial nucleus of c-Jun conditional knockout mice (Raivich et al., 2004), but its expression is unchanged in ATF3 transgenic mice. This implies that, although c-Jun is upregulated by ATF3 transgenic expression, this is not enough by itself to alter expression of $\alpha 7$ integrin, suggesting that its expression depends on additional signals in DRG neurons.

When cAMP is elevated in the DRG, neurites overcome myelin inhibition and axons grow in the spinal cord after a dorsal column lesion (Neumann et al., 2002; Qiu et al., 2002). cAMP signals through PKA to initiate CREB activation that then upregulates Arginase I with subsequent synthesis of polyamines. Polyamines probably act by affecting cytoskeleton assembly (Cai et al., 2002; Gao et al., 2004). PKA also inhibits RhoA activation, therefore preventing growth cone collapse. In addition, cAMP elevates IL-6, which signals via the JAK/ STAT pathway to overcome myelin inhibition (Cao et al., 2006). IL-6 signals through Janus kinases to activate STAT3, and both IL-6 knock-out and inhibition of STAT3 diminish the axonal growth evoked by a preconditioning injury (Cafferty et al., 2004; Qiu et al., 2005). An increase in STAT3 mRNA levels is detected in injured motor neurons (Schwaiger et al., 2000), but more striking is the change in its phosphorylation state after injury (Schwaiger et al., 2000; Qiu et al., 2005).

Although we found a modest increase in STAT3 mRNA level in the DRG after nerve injury, no change was found in the ATF3 transgenics. Similarly, no enhancement in STAT3 phosphorylation was identified in non-injured ATF3 transgenic mice (data not shown). In addition, GAP-43 mRNA levels were unchanged in the non-injured transgenic mouse DRG, implying that this prototypic growth-associated gene is not induced by ATF3 expression alone. Constitutive ATF3 expression appears to be functionally distinct from the effects of cAMP because it does not modify growth on myelin. Nevertheless, it is possible that transcription factors downstream of cAMP signaling could interact or act concurrently with ATF3 to enhance axonal growth and overcome inhibitory cues in the CNS.

Constitutive ATF3 expression drives altered expression of a set of genes in sensory neurons that are sufficient to enhance neurite elongation in vitro and the rate of peripheral nerve regeneration in vivo. Although ATF3 forced expression increases axonal growth in the PNS, it does not overcome myelin inhibition in culture or drive regeneration in the CNS. It is therefore likely that additional transcription factors operating either alone or in concert with ATF3 act to reduce the response to inhibitory cues. However, ATF3 even when expressed in non-injured neurons without additional signals, seems to be a major determinant of the intrinsic growth state of the neurons.

\section{References}

Aigner L, Arber S, Kapfhammer JP, Laux T, Schneider C, Botteri F, Brenner HR, Caroni P (1995) Overexpression of the neural growth-associated protein GAP-43 induces nerve sprouting in the adult nervous system of transgenic mice. Cell 83:269-278.

Benn SC, Perrelet D, Kato AC, Scholz J, Decosterd I, Mannion RJ, Bakowska JC, Woolf CJ (2002) Hsp27 upregulation and phosphorylation is required for injured sensory and motor neuron survival. Neuron 36:45-56. Bisby MA, Pollock B (1983) Increased regeneration rate in peripheral nerve axons following double lesions: enhancement of the conditioning lesion phenomenon. J Neurobiol 14:467-472.

Bloechlinger S, Karchewski LA, Woolf CJ (2004) Dynamic changes in glypican-1 expression in dorsal root ganglion neurons after peripheral and central axonal injury. Eur J Neurosci 19:1119-1132.

Bomze HM, Bulsara KR, Iskandar BJ, Caroni P, Skene JH (2001) Spinal axon regeneration evoked by replacing two growth cone proteins in adult neurons. Nat Neurosci 4:38-43.

Bonilla IE, Tanabe K, Strittmatter SM (2002) Small proline-rich repeat pro- 
tein $1 \mathrm{~A}$ is expressed by axotomized neurons and promotes axonal outgrowth. J Neurosci 22:1303-1315.

Cafferty WB, Gardiner NJ, Das P, Qiu J, McMahon SB, Thompson SW (2004) Conditioning injury-induced spinal axon regeneration fails in interleukin-6 knock-out mice. J Neurosci 24:4432-4443.

Cai D, Deng K, Mellado W, Lee J, Ratan RR, Filbin MT (2002) Arginase I and polyamines act downstream from cyclic AMP in overcoming inhibition of axonal growth MAG and myelin in vitro. Neuron 35:711-719.

Cai Y, Zhang C, Nawa T, Aso T, Tanaka M, Oshiro S, Ichijo H, Kitajima S (2000) Homocysteine-responsive ATF3 gene expression in human vascular endothelial cells: activation of c-Jun $\mathrm{NH}_{2}$-terminal kinase and promoter response element. Blood 96:2140-2148.

Cao Z, Gao Y, Bryson JB, Hou J, Chaudhry N, Siddiq M, Martinez J, Spencer T, Carmel J, Hart RB, Filbin MT (2006) The cytokine interleukin-6 is sufficient but not necessary to mimic the peripheral conditioning lesion effect on axonal growth. J Neurosci 26:5565-5573.

Caroni P (1997) Overexpression of growth-associated proteins in the neurons of adult transgenic mice. J Neurosci Methods 71:3-9.

Caroni P, Aigner L, Schneider C (1997) Intrinsic neuronal determinants locally regulate extrasynaptic and synaptic growth at the adult neuromuscular junction. J Cell Biol 136:679-692.

Chen MS, Huber AB, van der Haar ME, Frank M, Schnell L, Spillmann AA, Christ F, Schwab ME (2000) Nogo-A is a myelin-associated neurite outgrowth inhibitor and an antigen for monoclonal antibody IN-1. Nature 403:434-439.

Chong MS, Reynolds ML, Irwin N, Coggeshall RE, Emson PC, Benowitz LI, Woolf CJ (1994) GAP-43 expression in primary sensory neurons following central axotomy. J Neurosci 14:4375-4384.

Costigan M, Befort K, Karchewski L, Griffin RS, D’Urso D, Allchorne A, Sitarski J, Mannion JW, Pratt RE, Woolf CJ (2002) Replicate highdensity rat genome oligonucleotide microarrays reveal hundreds of regulated genes in the dorsal root ganglion after peripheral nerve injury. BMC Neurosci 3:16.

Curtis R, Stewart HJ, Hall SM, Wilkin GP, Mirsky R, Jessen KR (1992) GAP-43 is expressed by nonmyelin-forming Schwann cells of the peripheral nervous system. J Cell Biol 116:1455-1464.

Dergham P, Ellezam B, Essagian C, Avedissian H, Lubell WD, McKerracher L (2002) Rho signaling pathway targeted to promote spinal cord repair. J Neurosci 22:6570-6577.

Domeniconi M, Cao Z, Spencer T, Sivasankaran R, Wang K, Nikulina E, Kimura N, Cai H, Deng K, Gao Y, He Z, Filbin M (2002) Myelinassociated glycoprotein interacts with the Nogo66 receptor to inhibit neurite outgrowth. Neuron 35:283-290.

Domeniconi M, Zampieri N, Spencer T, Hilaire M, Mellado W, Chao MV, Filbin MT (2005) MAG induces regulated intramembrane proteolysis of the p75 neurotrophin receptor to inhibit neurite outgrowth. Neuron 46:849-855.

Gao Y, Deng K, Hou J, Bryson JB, Barco A, Nikulina E, Spencer T, Mellado W, Kandel ER, Filbin MT (2004) Activated CREB is sufficient to overcome inhibitors in myelin and promote spinal axon regeneration in vivo. Neuron 44:609-621.

Goodman CS (1996) Mechanisms and molecules that control growth cone guidance. Annu Rev Neurosci 19:341-377.

Gordon-Weeks PR (2004) Microtubules and growth cone function. J Neurobiol 58:70-83.

GrandPre T, Nakamura F, Vartanian T, Strittmatter SM (2000) Identification of the Nogo inhibitor of axon regeneration as a Reticulon protein. Nature 403:439-444.

GrandPre T, Li S, Strittmatter SM (2002) Nogo-66 receptor antagonist peptide promotes axonal regeneration. Nature 417:547-551.

Hai T, Curran T (1991) Cross-family dimerization of transcription factors Fos/Jun and ATF/CREB alters DNA binding specificity. Proc Natl Acad Sci USA 88:3720-3724.

Hai T, Hartman MG (2001) The molecular biology and nomenclature of the activating transcription factor/cAMP responsive element binding family of transcription factors: activating transcription factor proteins and homeostasis. Gene 273:1-11.

Hai T, Wolfgang CD, Marsee DK, Allen AE, Sivaprasad U (1999) ATF3 and stress responses. Gene Expr 7:321-335.

Heidemann SR (1996) Cytoplasmic mechanisms of axonal and dendritic growth in neurons. Int Rev Cytol 165:235-296.

Herdegen T, Fiallos-Estrada CE, Schmid W, Bravo R, Zimmermann M
(1992) The transcription factors c-JUN, JUN D and CREB, but not FOS and KROX-24, are differentially regulated in axotomized neurons following transection of rat sciatic nerve. Brain Res Mol Brain Res 14:155-165.

Hu-Tsai M, Winter J, Emson PC, Woolf CJ (1994) Neurite outgrowth and GAP-43 mRNA expression in cultured adult rat dorsal root ganglion neurons: effects of NGF or prior peripheral axotomy. J Neurosci Res 39:634-645.

Jankowski MP, Cornuet PK, McIlwrath S, Koerber HR, Albers KM (2006) SRY-box containing gene 11 (Sox11) transcription factor is required for neuron survival and neurite growth. Neuroscience 143:501-514.

Jenkins R, Hunt SP (1991) Long-term increase in the levels of c-jun mRNA and Jun protein-like immunoreactivity in motor and sensory neurons following axon damage. Neurosci Lett 129:107-110.

Koprivica V, Cho KS, Park JB, Yiu G, Atwal J, Gore B, Kim JA, Lin E, TessierLavigne M, Chen DF, He Z (2005) EGFR activation mediates inhibition of axon regeneration by myelin and chondroitin sulfate proteoglycans. Science 310:106-110.

Krekoski CA, Parhad IM, Clark AW (1996) Attenuation and recovery of nerve growth factor receptor mRNA in dorsal root ganglion neurons following axotomy. J Neurosci Res 43:1-11.

Leah JD, Herdegen T, Bravo R (1991) Selective expression of Jun proteins following axotomy and axonal transport block in peripheral nerves in the rat: evidence for a role in the regeneration process. Brain Res 566:198-207.

Lee N, Neitzel KL, Devlin BK, MacLennan AJ (2004) STAT3 phosphorylation in injured axons before sensory and motor neuron nuclei: potential role for STAT3 as a retrograde signaling transcription factor. J Comp Neurol 474:535-545.

Lehmann M, Fournier A, Selles-Navarro I, Dergham P, Sebok A, Leclerc N, Tigyi G, McKerracher L (1999) Inactivation of Rho signaling pathway promotes CNS axon regeneration. J Neurosci 19:7537-7547.

Lindwall C, Dahlin L, Lundborg G, Kanje M (2004) Inhibition of c-Jun phosphorylation reduces axonal outgrowth of adult rat nodose ganglia and dorsal root ganglia sensory neurons. Mol Cell Neurosci 27:267-279.

Liu BP, Fournier A, GrandPre T, Strittmatter SM (2002) Myelin-associated glycoprotein as a functional ligand for the Nogo-66 receptor. Science 297:1190-1193.

Makwana M, Raivich G (2005) Molecular mechanisms in successful peripheral regeneration. FEBS J 272:2628-2638.

Martin-Villalba A, Winter C, Brecht S, Buschmann T, Zimmermann M, Herdegen T (1998) Rapid and long-lasting suppression of the ATF-2 transcription factor is a common response to neuronal injury. Brain Res Mol Brain Res 62:158-166.

Mason MR, Lieberman AR, Grenningloh G, Anderson PN (2002) Transcriptional upregulation of SCG10 and CAP-23 is correlated with regeneration of the axons of peripheral and central neurons in vivo. Mol Cell Neurosci 20:595-615.

McQuarrie IG, Grafstein B, Gershon MD (1977) Axonal regeneration in the rat sciatic nerve: effect of a conditioning lesion and of dbcAMP. Brain Res 132:443-453.

Mi S, Miller RH, Lee X, Scott ML, Shulag-Morskaya S, Shao Z, Chang J, Thill G, Levesque M, Zhang M, Hession C, Sah D, Trapp B, He Z, Jung V, McCoy JM, Pepinsky RB (2005) LINGO-1 negatively regulates myelination by oligodendrocytes. Nat Neurosci 8:745-751.

Mills CD, Bitler JL, Woolf CJ (2005) Role of the peripheral benzodiazepine receptor in sensory neuron regeneration. Mol Cell Neurosci 30:228-237.

Morooka H, Bonventre JV, Pombo CM, Kyriakis JM, Force T (1995) Ischemia and reperfusion enhance ATF-2 and c-Jun binding to cAMP response elements and to an AP-1 binding site from the c-Jun promoter. J Biol Chem 270:30084-30092.

Mukhopadhyay G, Doherty P, Walsh FS, Crocker PR, Filbin MT (1994) A novel role for myelin-associated glycoprotein as an inhibitor of axonal regeneration. Neuron 13:757-767.

Nadeau S, Hein P, Fernandes KJ, Peterson AC, Miller FD (2005) A transcriptional role for C/EBP $\beta$ in the neuronal response to axonal injury. Mol Cell Neurosci 29:525-535.

Nakagomi S, Suzuki Y, Namikawa K, Kiryu-Seo S, Kiyama H (2003) Expression of the activating transcription factor 3 prevents c-Jun $\mathrm{N}$-terminal kinase-induced neuronal death by promoting heat shock protein 27 expression and Akt activation. J Neurosci 23:5187-5196.

Neumann S, WoolfCJ (1999) Regeneration of dorsal column fibers into and 
beyond the lesion site following adult spinal cord injury. Neuron 23:83-91.

Neumann S, Bradke F, Tessier-Lavigne M, Basbaum AI (2002) Regeneration of sensory axons within the injured spinal cord induced by intraganglionic cAMP elevation. Neuron 34:885-893.

Neumann S, Skinner K, Basbaum AI (2005) Sustaining intrinsic growth capacity of adult neurons promotes spinal cord regeneration. Proc Natl Acad Sci USA 102:16848-16852.

Oudega M, Varon S, Hagg T (1994) Regeneration of adult rat sensory axons into intraspinal nerve grafts: promoting effects of conditioning lesion and graft predegeneration. Exp Neurol 129:194-206.

Park JB, Yiu G, Kaneko S, Wang J, Chang J, He XL, Garcia KC, He Z (2005) A TNF receptor family member, TROY, is a coreceptor with Nogo receptor in mediating the inhibitory activity of myelin inhibitors. Neuron 45:345-351.

Pearson AG, Gray CW, Pearson JF, Greenwood JM, During MJ, Dragunow M (2003) ATF3 enhances c-Jun-mediated neurite sprouting. Brain Res Mol Brain Res 120:38-45.

Plunet W, Kwon BK, Tetzlaff W (2002) Promoting axonal regeneration in the central nervous system by enhancing the cell body response to axotomy. J Neurosci Res 68:1-6.

Pradervand S, Yasukawa H, Muller OG, Kjekshus H, Nakamura T, St. Amand TR, Yajima T, Matsumura K, Duplain H, Iwatate M, Woodard S, Pedrazzini T, Ross J, Firsov D, Rossier BC, Hoshijima M, Chien KR (2004) Small proline-rich protein $1 \mathrm{~A}$ is a gp130 pathway- and stress-inducible cardioprotective protein. EMBO J 23:4517-4525.

Qiu J, Cai D, Dai H, McAtee M, Hoffman PN, Bregman BS, Filbin MT (2002) Spinal axon regeneration induced by elevation of cyclic AMP. Neuron 34:895-903.

Qiu J, Cafferty WB, McMahon SB, Thompson SW (2005) Conditioning injury-induced spinal axon regeneration requires signal transducer and activator of transcription 3 activation. J Neurosci 25:1645-1653.

Raivich G, Bohatschek M, Da Costa C, Iwata O, Galiano M, Hristova M, Nateri AS, Makwana M, Riera-Sans L, Wolfer DP, Lipp HP, Aguzzi A, Wagner EF, Behrens A (2004) The AP-1 transcription factor c-Jun is required for efficient axonal regeneration. Neuron 43:57-67.

Richardson PM, Issa VM (1984) Peripheral injury enhances central regeneration of primary sensory neurones. Nature 309:791-793.

Sark MW, Fischer DF, de Meijer E, van de PP, Backendorf C (1998) AP-1 and Ets transcription factors regulate the expression of the human SPRR1A keratinocyte terminal differentiation marker. J Biol Chem 273:24683-24692.

Schwaiger FW, Hager G, Schmitt AB, Horvat A, Hager G, Streif R, Spitzer C, Gamal S, Breuer S, Brook GA, Nacimiento W, Kreutzberg GW (2000) Peripheral but not central axotomy induces changes in Janus kinases (JAK) and signal transducers and activators of transcription (STAT). Eur J Neurosci 12:1165-1176.

Seijffers R, Allchorne AJ, Woolf CJ (2006) The transcription factor ATF-3 promotes neurite outgrowth. Mol Cell Neurosci 32:143-154.

Shao Z, Browning JL, Lee X, Scott ML, Shulga-Morskaya S, Allaire N, Thill G,
Levesque M, Sah D, McCoy JM, Murray B, Jung V, Pepinsky RB, Mi S (2005) TAJ/TROY, an orphan TNF receptor family member, binds Nogo-66 receptor 1 and regulates axonal regeneration. Neuron 45:353-359.

Silver J, Miller JH (2004) Regeneration beyond the glial scar. Nat Rev Neurosci 5:146-156.

Sivasankaran R, Pei J, Wang KC, Zhang YP, Shields CB, Xu XM, He Z (2004) PKC mediates inhibitory effects of myelin and chondroitin sulfate proteoglycans on axonal regeneration. Nat Neurosci 7:261-268.

Sjoberg J, Kanje M (1990) The initial period of peripheral nerve regeneration and the importance of the local environment for the conditioning lesion effect. Brain Res 529:79-84.

Smith DS, Skene JH (1997) A transcription-dependent switch controls competence of adult neurons for distinct modes of axon growth. J Neurosci 17:646-658.

Snider WD, Zhou FQ, Zhong J, Markus A (2002) Signaling the pathway to regeneration. Neuron 35:13-16.

Spencer T, Filbin MT (2004) A role for cAMP in regeneration of the adult mammalian CNS. J Anat 204:49-55.

Strittmatter SM, Fankhauser C, Huang PL, Mashimo H, Fishman MC (1995) Neuronal pathfinding is abnormal in mice lacking the neuronal growth cone protein GAP-43. Cell 80:445-452.

Tanabe K, Bonilla I, Winkles JA, Strittmatter SM (2003) Fibroblast growth factor-inducible-14 is induced in axotomized neurons and promotes neurite outgrowth. J Neurosci 23:9675-9686.

Tsujino H, Kondo E, Fukuoka T, Dai Y, Tokunaga A, Miki K, Yonenobu K, Ochi T, Noguchi K (2000) Activating transcription factor 3 (ATF3) induction by axotomy in sensory and motoneurons: a novel neuronal marker of nerve injury. Mol Cell Neurosci 15:170-182.

Wallquist W, Zelano J, Plantman S, Kaufman SJ, Cullheim S, Hammarberg H (2004) Dorsal root ganglion neurons up-regulate the expression of laminin-associated integrins after peripheral but not central axotomy. J Comp Neurol 480:162-169.

Wang KC, Koprivica V, Kim JA, Sivasankaran R, Guo Y, Neve RL, He Z (2002) Oligodendrocyte-myelin glycoprotein is a Nogo receptor ligand that inhibits neurite outgrowth. Nature 417:941-944.

Werner A, Willem M, Jones LL, Kreutzberg GW, Mayer U, Raivich G (2000) Impaired axonal regeneration in $\alpha 7$ integrin-deficient mice. J Neurosci 20:1822-1830.

Williams KL, Rahimtula M, Mearow KM (2006) Heat shock protein 27 is involved in neurite extension and branching of dorsal root ganglion neurons in vitro. J Neurosci Res 84:716-723.

Xiao HS, Huang QH, Zhang FX, Bao L, Lu YJ, Guo C, Yang L, Huang WJ, Fu G, Xu SH, Cheng XP, Yan Q, Zhu ZD, Zhang X, Chen Z, Han ZG, Zhang $X$ (2002) Identification of gene expression profile of dorsal root ganglion in the rat peripheral axotomy model of neuropathic pain. Proc Natl Acad Sci USA 99:8360-8365.

Zhou XF, Rush RA, McLachlan EM (1996) Differential expression of the p75 nerve growth factor receptor in glia and neurons of the rat dorsal root ganglia after peripheral nerve transection. J Neurosci 16:2901-2911. 